\title{
Chondrocytic Potential of Allogenic Mesenchymal Stem Cells Transplanted without Immunosuppression to Regenerate Physeal Defect in Rabbits
}

\author{
P. GÁL ${ }^{1}$, A. NEČAS ${ }^{2}$, L. PLÁNKA ${ }^{1}$, H. KECOVÁ ${ }^{2}$, L. KŘEN ${ }^{3}$, P. KRUPA ${ }^{4}$, J. HLUČILOVÁ $^{5}$, D. USVALD \\ ${ }^{1}$ Department of Pediatric Surgery, Orthopaedics and Traumatology, The Faculty Hospital Brno, Czech Republic \\ ${ }^{2}$ Department of Surgery and Orthopaedics, Small Animal Clinic, Faculty of Veterinary Medicine, \\ University of Veterinary and Pharmaceutical Sciences Brno, Czech Republic \\ ${ }^{3}$ Department of Pathology, The Faculty Hospital Brno, Czech Republic \\ ${ }^{4}$ Department of Medical Imaging, St. Anne's University Hospital, Masaryk University, Brno, Czech Republic \\ ${ }^{5}$ Institute of Animal Physiology and Genetics of the Academy of Sciences of the Czech Republic, \\ Libechov, Czech Republic
}

Received December 28, 2006

Accepted January 4, 2007

\begin{abstract}
Gál P., A. Nečas, L. Plánka, H. Kecová, L. Křen, P. Krupa, J. Hlučilová, D. Usvald: Chondrocytic Potential of Allogenic Mesenchymal Stem Cells Transplanted without Immunosuppression to Regenerate Physeal Defect in Rabbits. Acta Vet. Brno 2007, 76: 265-275.

Mesenchymal stem cells (MSCs) from bone marrow are multipotent cells capable of forming cartilage, bone, and other connective tissues. The objective of this study was to determine whether the use of allogenic mesenchymal stem cells could functionally heal a defect in the distal femoral physis in rabbits without the use of immunosuppressive therapy.

A iatrogenic defect was created in the lateral femoral condyle of thirty-two New Zealand white rabbits, 7 weeks old, weighing $2.25 \pm 0.24 \mathrm{~kg}$. Each defect, $3.5 \mathrm{~mm}$ in width and $12 \mathrm{~mm}$ in length, in the right distal femoral physis was treated with allogenic mesenchymal stem cells in new composite hyaluronate/collagen type I/fibrin scaffold. The healing response was evaluated radiographically, by MRI (three weeks and four months after implantation) and also histologically, by Pearl's reaction and with immunofluorescence (four months after implantation). The results were compared with the data for the control defects (without stem cell implantation) in left distal femoral physes.

On average, right femurs with a damaged distal physis and transplanted MSCs grew more in length $(0.55 \pm 0.21 \mathrm{~cm})$ compared with left femurs with a physeal defect without stem cell transplantation $(0.46 \pm 0.23 \mathrm{~cm})$. Valgus deformity of right femurs with a physeal defect and transplanted MSCs was mild $\left(0.2 \pm 0.1^{\circ}\right)$. On the contrary, left femurs with a physeal defect without transplanted MSCs showed a significant valgus deformity $\left(2.7 \pm 1.6^{\circ}\right)$. For defects treated with allogenic mesenchymal stem cell implants, no adverse immune response and implant rejection were detected in this model. Histologically, no lymphocytic infiltration occurred. At four months after transplantation, hyaline cartilage had formed throughout the defects treated with allogenic MSCs. Labelled mesenchymal stem cells/differentiated chondrocytes were detected in the physeal defects based on magnetic resonance imaging and immunofluorescence.

The results of this study demonstrated that allogenic mesenchymal stem cells in a new composite hyaluronate/collagen type I/fibrin scaffold repaired iatrogenic defects in the distal femoral physes in rabbits without the use of immunosuppressive therapy. The use of allogenic mesenchymal stem cells for the repair of physeal defects may be an alternative to autologous MSCs transplantation. An allogenic approach would enable mesenchymal stem cells to be isolated from any donor, providing a readily available source of cells for cartilage tissue repair.
\end{abstract}

Growth plate injury, bone bridge, limb deformity, physeal repair, rejection

Trauma is a typical cause of defect in growth cartilage and the subsequent bone bridge formation. The standard surgical treatment method for bone growth defects due to closure of physeal growth cartilage consists of the resection of the bone bridge and corrective osteotomy (Bright 1984; Broughton et al. 1989; Klassen and Peterson 1982; Langenskiold 1981; Macksoud and Bright 1989; Williamson and Staheli 1990).

Address for correspondence:

Prof. MUDr. Petr Gál, Ph.D.

Department of Pediatric Surgery, Orthopedics and Traumatology

Medical Faculty, Masaryk's University

Černopolní 9

66263 Brno, Czech Republic

E-mail: petrgal@med.muni.cz

http://www.vfu.cz/acta-vet/actavet.htm 
More recently, cultured chondrocytes (Foster et al. 1990; Gál et al. 2002; Lee et al. 1998; Lennox et al. 1983; Nečas et al. 2006) and mesenchymal stem cell (Ahn et al. 2004; Chen et al. 2003; Plánka et al. 2007) transplantations represent an attractive and promising approach to treat physeal cartilage defects.

It is a well known fact that mesenchymal stem cells (MSCs) are multi-potent cells capable of differentiation not only into chondrocytes, but also into osteoblasts, adipocytes, tenocytes and myoblasts (Caplan et al. 1993; Jaiswal et al. 1997; Pittenger et al. 1999). After sampling of bone marrow blood by aspiration, MSCs can be isolated and, with regard to their proliferative capacity, cultivated and expanded to large numbers (Beresford 1989; Friedenstein et al. 1987; Lenn on et al. 1996). Mesenchymal stem cells have a characteristic immunological phenotype and specific cell surface markers SH- 2, 3, and 4. However, their surface lacks haematopoietic markers such as CD34 and CD45 (Bruder et al. 1997a; Haynesworth et al. 1992; Pittenger et al. 1999). It was also proven that MSCs remain functional not only after expansion by cultivation, but also after cryopreservation (Bruder et al. 1997b), which expands their potential for tissue therapy.

In our previous study, we showed that by delivering autologous mesenchymal stem cells on a suitable scaffold, we could enhance growth plate regeneration in a distal femoral physeal defect and thereby prevent bone bridge formation, bone shortening and angular deformity in rabbits (Plánka et al. 2007). Thus, the results of the study demonstrated the potential of the use of autologous mesenchymal stem cells in physeal cartilage repair. However, the transplantation of autologous MSCs in case of a physeal injury to a patient in clinical practice would first require bone marrow blood sampling by aspiration from this patient, subsequent several weeks long cultivation (expansion) of mesenchymal stem cells and then implantation to the defective spot. A clinically applicable alternative, however, could consist of bone marrow blood aspiration from a donor, isolation, expansion and cryopreservation of mesenchymal stem cells with subsequent transplantation when necessary (in this case to the injured physeal growth plate). This would constitute a possible "off-the-shelf" use of allogenic MSCs in therapy.

In case of such allogenic transplantation it is therefore expected that the donors and recipients are fully immunologically unrelated. This gives rise to the issue of possible adverse immune reaction and possible rejection of allogenic mesenchymal stem cells by the recipient. The results of previous studies suggest that MSCs might be immune privileged cells (Bartholomew et al. 2002; DiNicola et al. 2002). It is believed that surface characteristics of mesenchymal stem cells make it possible for them to avoid rejection. It was proven that mesenchymal stem cells do not express mesenchymal stem cell Class-II molecules and co-stimulatory molecules (B7 and CD40), which are necessary for full activation of $\mathrm{T}$ cells responsible for transplant rejection (Devine et al. 2001; McIntosh and Bartholomew 2000). Previous in vitro immunological studies prove the fact that mesenchymal stem cells do not provoke immune reaction if combined with allogenic lymphocytic cells (B artholomew et al. 2002; DiNicola et al. 2002).

This experimental study in the New-Zealand white rabbit focused on the testing of the ability (chondrogenic potential) of allogenic mesenchymal stem cells to elicit regeneration of iatrogenically damaged femoral distal growth plate without using immunosuppressive therapy. The goal was to confirm our working hypothesis that allogenic MSCs after in vivo transplantation into the injured physis do not provoke an adverse immune response, and to verify the ability of allogenic mesenchymal stem cells to stimulate and to participate in the healing of iatrogenically created physeal defect by newly created hyaline cartilaginous tissue. 


\section{Materials and Methods}

The New Zealand white rabbit (from a facility approved for laboratory animal breeding) was chosen as an experimental animal model. Thirty-two healthy individuals, 16 males and 16 females, of the same age ( 7 weeks) and approximately same weight $(2.25 \pm 0.24 \mathrm{~kg})$ were included in the study.

For the transplantation proper, we used allogenic mesenchymal stem cells (MSCs) prepared in the cytological laboratory of the Institute of Animal Physiology and Genetics of the Academy of Sciences of the Czech Republic, Liběchov) (IAPG AS CR). The cells came from unrelated rabbits used in another study. Twenty-one days before transplantation of MSCs to the recipient animal, a bone marrow blood sample was taken from the donor rabbits to culture the MSCs. The samples were taken under general anaesthesia. Induction was achieved by intramuscular administration of medetomidine at the dose of $200 \mu \mathrm{g} / \mathrm{kg}$ (DOMITOR inj. a.u.v., Pfizer) and ketamine $10 \mathrm{mg} / \mathrm{kg}$ (NARKAMON 5\% inj., Léčiva). Total intravenous anaesthesia (TIVA) was then maintained with propofol at the dose of $0.15 \mathrm{mg} / \mathrm{kg} / \mathrm{h}$ (PROPOFOL ABBOTT inj., Abbott Lab). Hypodermic needle (20G/40 mm) was used to take bone marrow blood in the syringe ( $5 \mathrm{ml}$, Baxter) with $2 \mathrm{ml}$ of PBS (Phosphate Buffered Saline, Dulbecco), $2 \%$ FBS (Fetal Bovine Serum, StemCell) and heparin at a dose of $5 \mathrm{IU} / \mathrm{ml}$. Puncture of wings of both ilia of seven-weekold donor rabbits yielded approximately $2 \mathrm{ml}$ of bone marrow blood.

Isolation, culturing, labelling and differentiation of cells

Blood plasma was removed from collected bone marrow blood by centrifugation $(400 \mathrm{~g}, 30 \mathrm{~min})$. Afterwards, opalescent film of mononuclear cells was skimmed for further isolation and culturing of bone marrow mesenchymal stem cells (MSCs) under laboratory conditions at $37^{\circ} \mathrm{C}$ and $5 \% \mathrm{CO}_{2}$. Culture medium Dulbecco's Modified Eagles Medium (DMEM) (Gibco Laboratories, Life Technologies, Grand Island, NY) supplemented with 10\% FBS and gentamycin (50mg/l, GENTAMYCIN, Sigma) was used. Cells were cultured on culture plates with the area of $0.75 \mathrm{~cm}^{2}$. After 24 hours, non-adherent cells were removed by rinsing the culture bottle with PBS solution. Culture medium was changed every three days. First colonies of MSCs occurred on days 4 to 5 . After 10 days, $80 \%$ of the culture plates were covered with cells. MSCs were washed in $0.5 \%$ solution of Trypsin and EDTA (Sigma) and layered to achieve a concentration of 5,000 - 6,000 cells $/ \mathrm{cm}^{2}$. The total number of isolated nuclear cells ranged from 15 to 30 million nuclear cells per each isolation (Plate XII, Fig. 1). Culturing of all samples of MSCs took 21 days.

Before they were transplanted to target tissue, the cultured bone marrow mesenchymal stem cells were labelled in two ways. First, they were labelled by a contrast consisting of paramagnetic iron oxide nanoparticles (Resovist, $0.5 \mathrm{mmol} \mathrm{Fe} / \mathrm{ml}$, Shering). Three days before transplantation, Resovist (at the concentration of $1 \mathrm{ml} / \mathrm{ml}$ ) was added to the culture medium containing the cells. Second, the cells were labelled by lipophilic fluorescent stain CM-DiI (Chloromethylbenzamido derivate of DiI, CellTracker ${ }^{\mathrm{TM}} \mathrm{CM}-\mathrm{DiI}$, Invitrogena) at the concentration of $5 \mu \mathrm{l} / 2.5 \mathrm{ml}$ of PBS. This labeller can be detected histologically using the immunofluorescence method. CM-DiI stain was added to MSCs after they were centrifuged $(700 \mathrm{~g}, 5 \mathrm{~min})$; incubation took 5 minutes at $37^{\circ} \mathrm{C}$, and 15 minutes at $4{ }^{\circ} \mathrm{C}$. Finally, MSCs were rinsed with PBS.

The cells were stimulated to differentiate towards chondrocytes as per the protocol (Miura 2002) for 30 minutes in $\alpha$-MEM medium with the supplement of $100 \mathrm{ng} / \mathrm{ml}$ of human recombinant TGF- $\beta_{1}$ (R\&D Systems), $1 \%$ ITS (Insulin - Transferrin - Selenium, Gibco), $100 \mathrm{nM}$ of dexamethasone (DEXAMETAZON, Medochemie) and 50 $\mathrm{mg} / \mathrm{ml}$ of ascorbate-2-phosphate solution (ASCORBÁT-2-FOSFÁT, Sigma). After induction, the cells were centrifuged ( $700 \mathrm{~g}, 5 \mathrm{~min})$ and prepared to be transferred to a scaffold.

Preparation of the scaffold

The scaffold was prepared at $4{ }^{\circ} \mathrm{C}$ by blending $20.75 \mu \mathrm{l}$ of sodium hyaluronate $(10 \mathrm{mg} / \mathrm{ml}, 1500 \mathrm{kDa}$ (SODIUM HYALURONAT, Contipro)) with $31.1 \mu \mathrm{l} 1 \mathrm{mg} / \mathrm{ml}$ of collagen type I solution (collagen type I was taken from calfskin kept in acid solvent) in 0.1-molar acetic acid (KYSELINA OCTOVÁ 99.8\%, Lachner s.r.o.). The scaffold was neutralized in 1-molar kalium hydroxide (potash) (HYDROXID DRASELNY, Penta). Afterwards, a pipette was used to add $36 \mu \mathrm{l}$ of MSCs suspension $\left(2 \times 10^{6}\right.$ of cells each time).

The medium containing $100 \mu \mathrm{g} / \mathrm{ml}$ of ascorbate-2-phosphate, $200 \mathrm{mM}$ of dexamethasone, $20 \%$ FBS and ITS was supplemented with $0.12 \mathrm{ml}$ solution of human protein for Tissucol (Tissucol ${ }^{\circledR}$ Kit Baxter) in aprotinin (fibrinogen $70-110 \mathrm{mg} / \mathrm{ml}$, aprotinin $3000 \mathrm{KIU} / \mathrm{ml}$ ) and $0.12 \mathrm{ml}$ of thrombin solution (4 IU/ml) in CaCl 2 (40 $\mu \mathrm{mol} / \mathrm{ml}$, Tissucol ${ }^{\circledR} \mathrm{Kit}$, Baxter). Gel was formed on a microtitration plate $(96$ wells $/ 300 \mathrm{ml} / \mathrm{well}$ diameter $0.628 \mathrm{~cm})(\mathrm{TPT})$ at $37^{\circ} \mathrm{C}$. Afterwards, the culture medium was added, and the scaffold was placed in the incubator with humid atmosphere of $5 \% \mathrm{CO}_{2}$ at $37^{\circ} \mathrm{C}$.

A mixture of scaffold and MSCs prepared in this way was kept in the incubator under the above mentioned conditions until the cells were implanted to the recipient animal (after 1 - 6 hours) .

\section{Surgical procedures}

Surgeries were performed under general anaesthesia. Before induction to anaesthesia enrofloxacin (BAYTRIL $2.5 \%$ inj. ad us. vet., Bayer) at a dose of $5 \mathrm{mg} / \mathrm{kg}$ was administered intravenously. Induction was achieved by intramuscular administration of midazolam $(1.00 \mathrm{mg} / \mathrm{kg}$ (DORMICUM inj., Roche) $)+$ fentanyl $(0.02 \mathrm{mg} / \mathrm{kg}$ (FENTANYL, Janssen) and medetomidine at the dose of $200 \mu \mathrm{g} / \mathrm{kg}$ (DOMITOR inj. a.u.v., Pfizer). Total inhalation anaesthesia was then maintained by a mixture of oxygen, nitrous oxide $(2: 3)$ and isoflurane (FORANE, Abbott Laboratoires) using a non-re-breathing system (Bain). Heart rate, respiratory rate, invasive blood pressure, end- 
tidal partial pressure of carbon dioxide and saturation of haemoglobin by oxygen was monitored (DATEX Cardiocap II). As this combination of drugs causes a strong respiratory depression, all animals were connected to a controlled ventilation device.

Rabbits were placed in dorsal recumbence and the surgical site was routinely prepared for aseptic procedure on both knees.

Lateral arthrotomy of the right stifle joint was performed by parapatellar incision. After visual localization of the growth plate, the battery-powered drill (Colibri system, SYNTHES, USA) was used to create a defect in the lateral part of the distal physis of the femur in order to cause damage exceeding $9 \%$ of the growth plate area (Gál et al. 2002; J a n arv et al. 1998). Therefore, $3.5 \mathrm{~mm}$ drill bit (ACUFEX - MosaicPlasty Precision, Smith \& Nephew, USA) was used to bore a canal $12 \mathrm{~mm}$ in depth from lateral surface of lateral condyle dorsolaterally above the insertion of $\mathrm{m}$. extensor digitorum longus. The canal was drilled in dorsomedial direction in order to cause damage of the lateral part of the distal femoral physis including adjacent parts of the epiphysis and metaphysis. Before implantation of the scaffold with allogenous MSCs, the canal was dilated using $3.5 \mathrm{~mm}$ dilator (ACUFEX MosaicPlasty Precision, Smith \& Nephew, USA). A mixture of the scaffold and MSCs was prepared in wells of a microtitration plate (TPT), from where the implant (in the form of a cylinder $3.5 \mathrm{~mm}$ thick and $10 \mathrm{~mm}$ long) was taken by the drill guide (ACUFEX - MosaicPlasty Precision, Smith \& Nephew, USA) and carefully inserted using a delivery tamp (ACUFEX - MosaicPlasty Precision, Smith \& Nephew, USA) into the defect drilled in the lateral femoral condyle. In order to fix the transplant in its position, the canal was closed (on the lateral surface of the lateral condyle of the femur) with a cylinder made from beta-tricalcium phosphate (ChronOS, SYNTHES) $3.5 \mathrm{~mm}$ thick and $2 \mathrm{~mm}$ long, that was cut out from a preformed ChronOS block using $3.5 \mathrm{~mm}$ tubular chisel (ACUFEX MosaicPlasty Precision, Smith \& Nephew, USA).

The stifle joint was lavaged with Ringer lactate solution (Ringer Lactat I.V.Inf., Braun Medical AG). The joint capsule was closed with interrupted suture (polypropylene, Prolene 4/0, Ethicon). Subcutaneous layer was closed with continuous suture using $2 / 0$ polyglactin 910 (Vicryl, Ethicon). The skin was closed with simple interrupted suture using 2/0 polyglactin 910 (Vicryl, Ethicon).

Afterwards, a defect in the lateral part of the distal epiphyseal plate of the left femur was created similarly. However, the canal drilled in the condyle was neither filled with an implant (i.e. the scaffold with allogenous MSCs), nor with beta-tricalcium phosphate (ChronOS). This limb served as a control.

After the surgery, antagonization of all three anaesthetic components was performed using a combination of naloxon $(0.03 \mathrm{mg} / \mathrm{kg}$ (INTRENON inj., Léčiva a.s.)) + flumazenil (0.1 mg/kg (ANEXATE, Hoffmann-La Roche Ltd.)) + atipamezol (1.0 mg/kg (ANTISEDAN inj. ad us. vet., Pfizer Animal Health)) that was administered intramuscularly. Analgesia in post-operative period was achieved by application of carprofen (RIMADYL inj. ad us. vet., Pfizer Animal Health) at a dose of $2 \mathrm{mg} / \mathrm{kg} /$ day for three days after the surgery.

Following recovery from surgery, the animals were allowed to walk freely and weight down as tolerated. During the whole study period, the animals were fed, handled and housed according to welfare principles (S ýk or a et al. 1983). At the end of the experiment (4 months after the surgery), all animals were euthanized lege artis. First, they were put under general anaesthesia using intravenous thiopental at a dose of $20 \mathrm{mg} / \mathrm{kg}$. Then they were given intravenous T 61 inj. ad us. vet. (Hoechst Roussel Vet.) at a dose of $1 \mathrm{ml}$ pro toto.

Length and angular (valgus) deformity of the operated bone was measured from radiographs in a craniocaudal (CC) projection. The quality of graft incorporation was evaluated histologically and using Pearl's reaction. Detection of the transplanted allogenic MSCs in the physeal defects was based on magnetic resonance imaging (MRI) and immunofluorescence. All procedures were carried out with the consent of the Ethical Committee (No. 46613/2003-1020).

Bone length discrepancy and femoral valgus deformity measurements

Each rabbit was subjected to radiological examination on the day of transplantation and immediately after euthanasia. Bone length discrepancy and valgus deformity were measured from radiographs. Measurement of the length of the right femur (with the physeal defect and transplanted MSCs) and the left femur (with the physeal defect without transplanted MSCs) was done from radiographs of the femur in a craniocaudal (CC) projection. The actual length of the femur and the angle of the valgus deformity of the distal femur were measured. The measurements were performed separately by three independent observers. The measured values were averaged to calculate the arithmetic mean.

\section{Magnetic resonance imaging}

In vivo detection of transplanted MSCs in the physeal defect was assessed by magnetic resonance imaging. Three weeks after the surgery and on the day of euthanasia, the rabbits were subjected to MRI examination - they were examined by the technique of T1 and T 2 weighted images and by the sequence modified to highlight hyposignal of MSCs labelled with iron oxide (detection of paramagnetic iron oxide nanoparticles, Resovist). A three-week interval between the transplantation and the first MRI examination selected to eliminate possible formation of artifacts caused by post-operative haematoma (Anderson et al. 2004).

Histological findings

Healing of the defect was investigated histologically, using haematoxylin and eosin staining. Femurs were extracted and placed in a fixative $10 \%$ solution of buffered formalin for 48 hours. Femurs were decalcified in a solution of hydrochloric acid and ferric chloride (changed every 12 hours) for 5 to 8 days. Following complete 
decalcification, the resected samples were sectioned in a way to reveal the longitudinal axis of the canal drilled. Parts of the growth plates with the lesions were excised together with at least $1 \mathrm{~cm}$ of the surrounding tissue. They were histologically processed and stained with haematoxylin and eosin. Sections $6 \mu \mathrm{m}$ in depth were examined and photographed using an optic microscope Nikon Eclipse 1000. Incorporation of the transplant into the canal drilled through the growth plate was evaluated. The defects filled with MSCs in the right distal femoral physis were histologically compared with unfilled left femoral physeal defects.

On the basis of immunofluorescence detection of CM-DiI stain incorporated into the cell wall, these examinations should have proved, whether chondrocytes present in the defect come from the implanted colony of allogenous MSCs or not.

Statistical evaluation

Means and standard deviations were calculated for the length and valgus deformity of the right femur (with the physeal defect and transplanted MSCs) and the left femur (with the physeal defect without transplanted MSCs) as well as for differences in length and angular deformities before MSCs transplantation and after euthanasia. The values were statistically analyzed using Wilcoxon matched-pairs test; STATISTICA (data analysis software system), version 7.1 (StatSoft, Inc. 2005).

\section{Results}

In all thirty-two rabbits, we successfully cultured MSCs allotransplant in the required quality with the average count of cells $29 \times 10^{6}\left(29 \pm 2 \times 10^{6}\right)$. The allogenic MSCs were successfully implanted into iatrogenic distal femoral physeal defects. There were no anaesthesia and post-operative complications in any of the animals. The wounds healed per primam intentionem, and no clinical adverse host response to allogenous MSCs transplantation into iatrogenically damaged physes without immunosuppression could be detected.

Results of measurement of femur lengths showed that right femurs with a damaged distal growth zone and transplanted MSCs grew more in length $(0.55 \pm 0.21 \mathrm{~cm})$ as compared with left femurs with the physeal defect without transplanted MSCs $(0.46 \pm 0.23 \mathrm{~cm})$. Angular (valgus) deformity of right femurs with the physeal defect and transplanted MSCs was mild $\left(0.2 \pm 0.1^{\circ}\right)$. On the contrary, left femurs with the physeal defect without transplanted MSCs showed significant valgus deformity $\left(2.7 \pm 1.6^{\circ}\right)$. Differences in lengths and valgus deformity were statistically significant ( $1 \%$ level of significance, $p=$ $0.001)$.

Table 1 shows the results of examinations of the distal femoral physeal defects with MRI, the results of histological examination of samples, Pearl's reaction and the results of detection of transplanted allogenic MSCs by immunofluorescence.

MRI examination proved the presence of paramagnetic nano-particles of iron oxide in the place of transplantation of marked allogenic MSCs in the lateral section of the right femoral condyle in $85 \%$ of cases (in 27 out of 32 animals) (Plate XII, Fig. 2). Such marked MSCs were not proven by this method in five cases (rabbits AL12, AL13, AL16, AL25, and AL30).

Histological examination of sections of the distal portion of the femur coloured with haematoxylin-eosin proved the presence of chondrocytes in this physeal section after transplantation of allogenic MSCs into places of experimentally created defects in the distal growth plate of the right femur. At eighteen weeks, hyaline cartilage had formed throughout the defects treated with allogenic MSCs. Histologically, we found two forms of newly created cartilaginous tissue in the place of MSCs transplantation, namely enclaves of chondrocytes (Plate XII, Fig. 3a) or a massive filling of the physeal defect with hyaline cartilage (Plate XII, Fig. 3b). In five cases, no chondrocytes were found in the physeal defect treated with transplantation of allogenic MSCs. These were the rabbits in which MRI proved no presence of paramagnetic nano-particles of iron oxide in the place of transplantation (rabbits AL12, AL13, AL16, AL25, and AL30). No adverse host response, in terms of lymphocytic infiltration on allogenic MSCs transplantation without immunosuppression was histologically detected. 
In 27 out of 32 experimental animals (Table 1) we proved the presence of transplanted mesenchymal stem cells, or cells differentiated from these implanted allogenic MSCs. In 26 cases we managed to prove the presence of these cells with MRI, histological examination, Pearls reaction (Plate XIII, Fig. 4), and immunofluorescence simultaneously (Plate XIII, Fig. 5). In one case (rabbit AL20) we proved the presence of transplanted MSCs (or cells differentiated from them) with the aforementioned methods excluding immunofluorescence (Table 1).

Table 1. Results of MRI and histological examination (HE, Pearl's reaction, immunofluorescence examination) of dissections of right distal femoral physis in rabbits.

\begin{tabular}{|c|c|c|c|c|c|}
\hline & $\begin{array}{c}\text { MRI proof of MSCs } \\
\text { with Resovist } \\
\text { (after } 3 \text { weeks) }\end{array}$ & $\begin{array}{c}\text { MRI proof of MSCs } \\
\text { with Resovist } \\
\text { (after } 4 \text { months }\end{array}$ & $\begin{array}{c}\text { Result of histological } \\
\text { finding HE } \\
\text { (after } 4 \text { months) }\end{array}$ & $\begin{array}{l}\text { Proof of MSCs } \\
\text { with Pearl's reaction } \\
\text { (after } 4 \text { months) }\end{array}$ & $\begin{array}{l}\text { Proof of MSCs with } \\
\text { immunofluorescence } \\
\text { (after } 4 \text { months) }\end{array}$ \\
\hline AL01 & + & + & ++ & + & + \\
\hline AL02 & + & + & ++ & + & + \\
\hline AL03 & + & + & ++ & + & + \\
\hline AL04 & + & + & ++ & + & + \\
\hline AL05 & + & + & ++ & + & + \\
\hline AL06 & + & + & ++ & + & + \\
\hline AL07 & + & + & ++ & + & + \\
\hline AL08 & + & + & ++ & + & + \\
\hline AL09 & + & + & ++ & + & + \\
\hline AL10 & + & + & ++ & + & + \\
\hline AL11 & + & + & ++ & + & + \\
\hline AL12 & + & - & - & - & - \\
\hline AL13 & + & - & - & - & - \\
\hline AL14 & + & + & ++ & + & + \\
\hline AL15 & + & + & ++ & + & + \\
\hline AL16 & + & - & - & - & - \\
\hline AL17 & + & + & ++ & + & + \\
\hline AL18 & + & + & ++ & + & + \\
\hline AL19 & + & + & ++ & + & + \\
\hline AL20 & + & + & ++ & + & - \\
\hline AL21 & + & + & ++ & + & + \\
\hline AL22 & + & + & ++ & + & + \\
\hline AL23 & + & + & ++ & + & + \\
\hline AL24 & + & + & ++ & + & + \\
\hline AL25 & + & - & - & - & - \\
\hline AL26 & + & + & ++ & + & + \\
\hline AL27 & + & + & ++ & + & + \\
\hline AL28 & + & + & ++ & + & + \\
\hline AL29 & + & + & ++ & + & + \\
\hline AL30 & + & - & - & - & - \\
\hline AL31 & + & + & ++ & + & + \\
\hline AL32 & + & + & + & + & + \\
\hline
\end{tabular}

+ ) examination positive $\quad-$ MRI - finding of iron oxide labeled MSCs in the place of transplantation

- Pearl's reaction - presence of iron particles in the cytoplasm of chondrocytes

- Immunofluorescence - finding of fluorescence hue on the membranes of chondrocytes

- Histology - finding of chondrocyte enclaves in the physeal defect

++ ) histological finding (HE) - defect filled with hyaline cartilage without columnar cell formation

-) microscopic examination found no chondrocytes in the defect 


\section{Discussion}

In our previous study focused on preventive transplantation of autologous MSCs into the defect in the femoral distal growth plate of the rabbit, hyaline cartilage was formed 4 months after implantation on the site of the original iatrogenic physeal defect (Plánka et al. 2007). Recently the focus of scientific interest has shifted from autologous MSCs implantations towards allogenic cell transplantations. Some authors suggest that there is no need for immunosuppressive therapy in cases of allogenic mesenchymal stem cell transplantation (Chiu et al. 2006; Batten et al. 2006; Plumas et al. 2005; Caparreli et al. 2001). They describe the immunomodulation effect of MSCs, which itself leads to immunosuppression by inactivating CD4+ T lymphocytes (Batten et al. 2006), or induction of apoptosis of activated T lymphocytes (Plumas et al. 2005; Frank et al. 2004). The aforementioned immunomodulation ability of MSCs is taken a step further in our study - this characteristic was successfully used to cure systemic diseases (scleroderma, multiple sclerosis, rheumatoid arthritis, juvenile idiopathic arthritis and systemic lupus erythematosus). Implanted allogenic MSCs induced a certain type of immunosuppression used in the treatment of these autoimmune diseases (Laar et al. 2006). To our knowledge, this study is the first experimental work that describes a successful allogenic transplantation of mesenchymal stem cells without using immunosuppressive therapy in the repair of a damaged physis in the rabbit. Its results suggest that allogenic mesenchymal stem cells in the rabbit demonstrate a chondrogenic potential with the ability to elicit and participate in the repair of the iatrogenically damaged femoral distal growth plate with newly created hyaline cartilaginous tissue. The repair of cartilaginous tissue of the right femoral distal physis after transplantation of allogenic MSCs was clinically proven by different bone growth compared to the left femur (without transplanted MSCs). The right femur with a defect in the lateral section of the growth plate and transplanted MSCs was longer and less valgus deformed than the left femurs with the same physeal defect without MSCs transplantation. The average difference in the femoral length between operation and euthanasia (i.e. the scope of the bone growth) was, in case of the right femur after preventive transplantation MSCs $0.55 \pm 0.21 \mathrm{~cm}$, whereas in case of the left femur it was only $0.46 \pm 0.23 \mathrm{~cm}$. The average angular (valgus) deformity of the right femur with preventively transplanted MSCs into the iatrogenically created defect in the femoral distal physis was 0.2 $\pm 0.1^{\circ}$, whereas in case of the left femur its valgus deformity was $2.7 \pm 1.6^{\circ}$. The difference in the measured values of both parameters was statistically significant at $1 \%$ significance level $(p=0.001)$. The right femur, in contrast to the left femur, grew more in length. Its valgus deformity, compared to the left femur, was minimal and clinically non-significant.

The selection of an appropriate method of isolation, culturing, differentiation of cells and preparation of scaffold material for mesenchymal stem cell use in physeal cartilage repair is also a very important factor for successful MSCs implantation. In our study, the MSCs were separated from bone marrow blood taken from the ilium. Cultured MSCs were stimulated to differentiate towards chondrocytes as per protocol ( Mi u r a 2002) in $\alpha$-MEM medium with the supplement of human recombinant TGF- $\beta 1$. The culture medium was supplemented also with $1 \%$ ITS, dexamethasone and ascorbate-2-phosphate which are commonly used ingredients of culture and differentiation medium ( $\mathrm{Li}$ et al. 2005; Lisignoli et al. 2005; Indrawattana et al. 2004; Quintavalla et al. 2002). A new three-component scaffold (New Composite Hyaluronate/Collagen Type I/Fibrin Scaffold), whose characteristics are similar to the natural environment of cartilaginous extracellular matrix, was used. We also found a suitable technique of implant delivery to the site of the damaged distal physis of the femur using ACUFEX (MosaicPlasty Precision) instruments.

Under the conditions of this experiment, allogenic MSCs after in vivo transplantation into the injured physis without concomitant immunosuppressive therapy elicited no adverse 
immune response. Clinically, no complications with defect healing in the physis or with the healing of the surgical wound were recorded after implantation of allogenic MSCs without immunosuppression. Histologically, no adverse local immune response in the form of lymphocytic infiltration in the place of MSCs implantation was recorded either. Moreover, 4 months after the implantation of allogenic MSCs a newly created hyaline cartilaginous tissue was histologically confirmed in the place of the iatrogenically created physeal defect, which proves that the transplanted stem cells remained viable during the growth plate recovery and participated in the healing process of the physeal defect.

In $85 \%$ of cases ( 27 out of 32 animals) we proved using MRI, histology, Pearl's reaction and immunofluorescence, the presence of transplanted mesenchymal stem cells, or cells differentiated from these implanted allogenic MSCs. In one instance, when chondrocytes were possible to detect with standard histological colouring, they were not detected by immunofluorescence (Table 1). Proof of the presence of paramagnetic nano-particles of iron oxide by MRI ( 3 weeks and 4 months after implantation of MSCs) and immunofluorescence proof of cells stained with DiI (4 months after implantation of MSCs) in the place of transplantation of labelled allogenic MSCs in the lateral section of the right femoral condyle testifies that the implanted stem cells underwent chondrogenic differentiation and started to generate cartilaginous tissue in the damaged physis. Fluorescence-labelled cells were detected in a smaller than original amount 4 months after transplantation. There are several possible explanations to this. One version suggests that the immunofluorescence-labelled MSCs were impossible to detect after such a long period because of dilution of the fluorescent cytoplasmic label during mitosis and the subsequent differentiation of mesenchymal stem cells. It is also possible that the MSCs differentiated into mature chondrocytes (chondroblasts) and then succumbed to apoptosis.

The findings of this study - that the allogenic MSCs can be successfully transplanted into a physeal defects without immunosuppression - support the hypothesis that the mesenchymal stem cells may be immune-privileged cells ( B artholomew et al. 2002). It was also proven that the mesenchymal stem cells do not express mesenchymal stem cell Class-II molecules or co-stimulatory molecules (B7 and CD40) (Hock et al. 2001). Besides, they may also secrete certain factors that suppress the immune response (Krebsbach et al. 1997). The allogenic transplantation of MSCs into a partial defect of the growth zone that was carried out in the study proves the capacity of differentiation and survival of these cells in the target tissue without transplant rejection or the occurrence of graft-versus-host disease, even without immunosuppressive therapy. In spite of the very favourable results, we must continue verifying the method in other animal species before clinical application. And, last but not least, we must carry out long-term monitoring of animals with implanted MSCs from the standpoint of possible adverse complications of stem cells.

It also appears to be desirable to test the application of xenologous MSCs with similar indication on suitable models. Immunotolerance of mesenchymal stem cells was also described in xenotransplantations. In 2000, Liechty et al. carried out a successful transplantation of human MSCs into a sheep foetus in utero. It was an innovative idea - to expose an underdeveloped immunity system of a sheep foetus to the effects of a xenostransplant. Other studies describe xenotransplantation of human cells into the bones of laboratory rats (Fatkhudinov et al. 2005) or transplantation of mouse MSCs into the tissues of mature, fully immunocompetent rats ( $S$ aito et al. 2002). No transplant rejection was described here either. The aforementioned results may constitute a guide to the scenario when it will be possible to produce, in vitro multiply and cryopreserved allogenic or xenologous mesenchymal stem cells for immediate clinical use without any immunosuppression.

In conclusion, our results demonstrated that hyaline cartilage formation occurs in 
iatrogenic distal femoral physeal defects treated with allogenic mesenchymal stem cells. Newly formed cartilage in the growth plate area became well integrated with the host physis and functional. The continued growth of the right femur from its distal physis was apparent. This study is the first report, to our knowledge, of the use of allogenic mesenchymal stem cells for repair of experimentally damaged physis in rabbits.

\section{Chondrogenní potenciál allogenních mezenchymových kmenových buněk transplantovaných bez imunosuprese k regeneraci fyzárních defektů u králíků}

Mezenchymové kmenové buňky (MSCs) kostní dřeně jsou multipotentní buňky schopné diferencovat v kost, chrupavku a další pojivové tkáně. Cílem této studie bylo zjistit, zda allogenní mezenchymové kmenové buňky mohou bez imunosupresní terapie funkčně zhojit defekt v distální růstové ploténce femuru králíka.

U 32 novozélandských bílých králíků, stáří 7 týdnů a tělesné hmotnosti 2,25 $\pm 0,24 \mathrm{~kg}$ byl v laterálním kondylu femuru iatrogenně vytvořen defekt. Do tohoto defektu, o šířce 3,5 mm a hloubce $12 \mathrm{~mm}$, vyvrtaného distální fýzy pravého femuru byly implantovány allogenní mezenchymové kmenové buňky v novém kompozitním nosiči (hyaluronát/kolagen typu I/fibrin). Hojení defektu ve fýze bylo hodnoceno rentgenologicky, magnetickou rezonancí (3 týdny a 4 měsíce po implantaci), histologicky, Pearlsovou reakcí a imunofluorescenčně (4 měsíce po implantaci). Výsledky byly porovnány s údaji zjiššenými vyšetřením kontrolních defektů (bez implantace kmenových buněk) v distální fýze levého femuru.

Pravé femury s poškozenou distální fýzou a transplantovanými MSCs rostly do délky více $(0,55 \pm 0,21 \mathrm{~cm})$, než levé femury s defektem v distální fýze bez transplantace kmenových buněk $(0,46 \pm 0,23 \mathrm{~cm})$. Valgózní deformita pravých femurů s defektem fýzy a transplantovanými MSCs byla nepatrná $\left(0,2 \pm 0,1^{\circ}\right)$. Naproti tomu levé femury s defektem distální fýzy bez transplantace MSCs vykazovaly signifikantní valgózní deformitu $\left(2,7 \pm 1,6^{\circ}\right)$. V tomto modelu defektů distální fýzy femuru ošetřených transplantací allogenních mezenchymových kmenových buněk nebyla klinicky pozorována žádná nežádoucí imunitní reakce ani rejekce implantátu. Stejně tak histologicky nebyla zjištěna žádná lokální nežádoucí reakce v podobě lymfocytární infiltrace. Čtyři měsíce po transplantaci allogenních MSCs vytvořena hyalinní chrupavka. Značené mezenchymové kmenové buňky/diferencované chondrocyty byly po transplantaci detekovány ve fyzárních defektech magnetickou rezonancí a imunofluorescenčně.

Výsledky této studie dokazují, že allogenní mezenchymové kmenové buňky v novém kompozitním nosiči (hyaluronát/kolagen typu I/fibrin) zhojily iatrogenní defekty v distální fýze femuru králíků bez použití imunosupresní terapie. Použití allogenních mezenchymových kmenových buněk může tedy být v léčbě fyzárních defektů alternativou autologní transplantace MSCs. Tato allogennní transplantace by mohla v praxi znamenat izolaci MSCs od nepříbuzného dárce, tedy snadno dostupný zdroj buněk potřebných pro hojení chrupavčité tkáně.

\section{Acknowledgement}

This work was supported by the Ministry of Health of the Czech Republic (Research Projects of IGA MZ CR NR8483-2/2005) and Ministry of Education, Youth and Sport of the Czech Republic (NPV II 2B06130) and by Grant Agency AGEL-MH. We are grateful to Mgr. Eva Filová and Doc. RNDr. Evžen Amler for providing scaffolds used in the study.

\section{References}

AHN JI, CANALE TS, BUTLER SD, HASTY KA 2004: Stem cell repair of physeal cartilage. J Orthop Res 22: 1215-1221

ANDERSON SA, GLOD J, ARBAB AS, NOEL M, ASHARI P, FINE HA, FRANK JA 2004: Non-Invasive MR Imaging of Magnetically Labeled Stem Cells to Directly Identify Neovasculature in a Glioma Model. Blood first edition paper, prepublished online August 26, DOI 10.1182. 
BARTHOLOMEW A, STURGEON C, SIATSKAS M, FERRER K, MCINTOSH K, PATIL S, HARDY W, DEVINE S, UCKER D, DEANS R, MOSELEY A, HOFFMAN R 2002: Mesenchymal stem cells suppress lymphocyte proliferation in vitro and prolong skin graft survival in vivo. Exp Hematol 30: 42-48

BATTEN P, SARATHCHANDRA P, ANTONIW JW, TAY SS 2006: Human mesenchymal stem cells induce $\mathrm{T}$ cell anergy and downregulate $\mathrm{T}$ cell allo-responses via the $\mathrm{TH} 2$ pathway: Relevance to tissue engineering human heart valves. Tissue Eng Larchmont 12: 2263

BERESFORD JN 1989: Osteogenic stem cells and the stromal system of bone and marrow. Clin Orthop 240: 270-280

BRIGHT RW 1974: Operative correction of partial epiphyseal plate closure by osseous-bridge resection and silicon-rubber implant. J Bone Joint Surg Am 56: 655-664

BROUGHTON NS, DICKENS DRV, COLE WG, MENELAUS MB 1989: Epiphysiolysis for partial growth plate arrest. J Bone Join Surg Br 71: 13-16

BRUDER SP, HOROWITZ MC, MOSCA JD, HAYNESWORTH SE 1997a: Monoclonal antibodies reactive with human osteogenic cell surface antigens. Bone 21: 225-235

BRUDER SP, JAISWAL N, HAYNESWORTH SE 1997b: Growth kinetics, self-renewal, and the osteogenic potential of purified human mesenchymal stem cells during extensive subcultivation and following cryopreservation. J Cell Biochem 64: 278-294

CAPARRELLI DJ, CATTANEO E, SHAKE JG 2001: Cellular cardiomyoplasty with allogenic mesenchymal stem cells results in improved cardiac performance in a swine model of myocardial infarction. Circulation 104: 11-59

CAPLAN AI, FINK DJ, GOTO T, LINTON AE, YOUNG RG, WAKITANI S, GOLDBERG VM, HAYNESWORTH SE 1993: Mesenchymal stem cells and tissue repair. In: JACKSON DW, ARNOCZKY SR, WOO SL, FRANK CB, SIMON TM: The anterior cruciate ligament: current and future concepts. New York: Raven Press pp. 405-417

DEVINE SM, PETER S, MARTIN BJ, BARRY F, MCINTOSH KR 2001: Mesenchymal stem cells: stealth and suppression. Cancer J 7: S76-82

DINICOLA M, CARLO-STELLA C, MAGNI M, MILANESI M, LONGONI PD, MATTEUCCI P, GRISANTI S, GIANNI AM 2002: Human bone marrow stromal cells suppress T-lymphocyte proliferation induced by cellular or nonspecific mitogenic stimuli. Blood 99: 3838-3843

FATKHUDINOV TK, GOL'DSHTEIN DV, PULIN AA, SHAMENKOV DA 2005: Reparative osteogenesis during transplantation of mesenchymal stem cells. Bull Exp Biol Med 140: 96

FOSTER BK, HANSEN AL, GIBBON GJ 1990: Reimplantation of growth plate chondrocytes into growth plate defects in Wheel. J Orthop Res 8: 555-564

FRANK MH, SAYEGH MH 2004: Immunomodulatory functions of mesenchymal stem cells. Lancet 363: 1411

FRIEDENSTEIN AJ, CHAILAKHYAN RK, GERASIMOV UV 1987: Bone marrow osteogenic stem cells: in vitro cultivation and transplantation in diffusion chambers. Cell Tissue Kinet 20: 263-272

GÁL P, NEČAS A, ADLER J, TEYSCHL O, FABIÁN P, BIBROVÁ Š 2002: Transplantation of the autologous chondrocyte graft to physeal defects: An experimental study in pigs. Acta Vet Brno 71: 327- 332

GÁL P, TEYSCHL O, KECOVÁ H, FABIÁN P, BIBROVÁ Š 2002: Influence of transphyseal pin placement on bone growth: An experimental study in pigs. Acta Vet Brno 71: 319-325

HANSEN AL, FOSTER BK, GIBBON GJ 1990: Growth-plate chondrocyte cultures for reimplantation into growth-plate defects in wheel: characterisation of culture. Clin Orthop 256: 286-298

HAYNESWORTH SE, BABER MA, CAPLAN AI 1992: Cell surface antigens on human marrow-derived mesenchymal cells are detected by monoclonal antibodies. Bone 13: 69-80

HOCK JM, KRISHNAN V, ONYIA JE, BIDWELL JP, MILAS J, STANISLAUS D 2001: Osteoblast apoptosis and bone turnover. J Bone Miner Res 16: 975-984

CHEN F, HUI JHP, CHAN WK, LEE EH 2003: Cultured mesenchymal stem cell transfers in the treatment of partial growth arrest. J Pediatr Orthop 23: $425-429$

CHIU RCJ 2003: Bone-marrow stem cells as a source for cell therapy, Heart Failure Reviews. Norwell 8: 247

INDRAWATTANA N, CHEN G, TADOKORO M, SHANN LH, OHGUSHI H, TATEISHI T, TANAKA J, BUNYARATVEJ A 2004: Growth factor combination for chondrogenic induction from human mesenchymal stem cell. Biochem Biophys Res Commun 320:914-919

JANARV PM, WIKSTRÖM B, HIRSCH G 1998: The influence of transphyseal drilling and tendon grafting on bone growth: an experimental study in the rabbit. J Pediatr Orthop 18: 149-154

JAISWAL N, HAYNESWORTH SE, CAPLAN AI, BRUDER SP 1997: Osteogenic differentiation of purified, culture-expanded human mesenchymal stem cells in vitro. J Cell Biochem 64: 295-312

KLASSEN RA. PETERSON MA 1982: Excision of physeal bars: the Mayo Clinic experience 1968-1978. Orthop Trans 2: 65

KREBSBACH PH, KUZNETSOV SA, SATOMURA K, EMMONS RV, ROWE DW, ROBEY PG 1997: Bone formation in vivo: comparison of osteogenesis by transplanted mouse and human marrow stromal fibroblasts. Transplantation 63: 1059-1069

LAAR JM, TYNDALL A 2006: Adult stem cells in the treatment of autoimmune diseases. Rheumatology 45: 1187

LANGENSKIOLD A 1981: Surgical treatment of partial closure of the growth plate. J Pediatr Orthop 1: 3-11 
LEE EH, CHEN F, CHAN WK 1998: Treatment of growth arrest by transfer of cultured chondrocytes into physeal defects. J Pediatr Orthop 18: 155-160

LENNON DP, HAYNESWORTH SE, BRUDER SP, JAISWAL NJ, CAPLAN AI 1996: Human and animal mesenchymal progenitor cells from bone marrow: identification of serum for optimal selection and proliferation. In Vitro Cell Dev Biol 32: 602-611

LENNOX DW, GOLDNER RD, SUSSMAN MD 1983: Cartilage as an interposition material to prevent transphyseal bone bridge formation: an experimental model. J Pediatr Orthop 3: 207-210

LI WJ, TULI R, OKAFOR C, DERFOUL A, DANIELSON KG, HALL DJ, TUAN RS 2005: A three-dimensional nanofibrous scaffold for cartilage tissue engineering using human mesenchymal stem cells. Biomaterials 26:599-609

LIECHTY KW, MACKENZIE TC, SHAABAN AF 2000: Human mesenchyma1 stem cells engraft and demonstrate sitaspecific differentiation after in utero transplantation in sheep. Nature Med 11: 1282- 1286

LISIGNOLI G, CRISTINO S, PIACENTINI A, TONEGUZZI S, GROSSI F, CAVALLO C, ZINI N, SOLIMANDO L, NARALDI NM, FICCHINI A 2005: Cellular et molecular events during chondrogenesis of human mesenchymalstromal cells grown in three-dimensional hyaluronan based scaffold. Biomaterials 26: 5677-5686

MACKSOUD WS, BRIGHT R 1989: Bar resection and silastic interposition in distal radial physeal arrest. Orthop Trans 13: 1-2

MCINTOSH K, BARTHOLOMEW A 2000: Stromal cell modulation of the immune system. A potential role for mesenchymal stem cells. Graft 3: $324-328$

NEČAS A, GÁL P, ADLER J, KECOVÁ H, FABIÁN P, BIBROVÁ Š 2006: Transplantation of the autologous chondrocyte graft to physeal defects: An experimental study. Proceedings of the 2nd Annual World Orthopedic Congress, 25.2. - 4.3.2006, Keystone, Colorado, USA, p. 236

MIURA Z, PARVIZI J, FITZSIMMONS JS, ODRISCOLL SW 2002: Brief exposure to high-dose transforming growth factor-betal enhances periosteal chondrogenesis in vitro: a preliminary report. J Bone Joint Surg Am 84-A: 793-799

PITTENGER MF, MACKAY AM, BECK SC, JAISWAL RK, DOUGLAS R, MOSCA JD, MOORMAN MA, SIMONETTI DW, CRAIG S, MARSHAK DR 1999: Multilineage potential of adult human mesenchymal stem cells. Science 284: 143-147

PLÁNKA L, NEČAS A, GÁL P, KECOVÁ H, FILOVÁ H, KŘEN L, KRUPA P 2007: Prevention of bone bridge formation using transplantation of the autologous mesenchymal stem cells to physeal defects: An experimental study in rabbits. Acta Vet Brno 76: 253-263

PLUMAS J, CHAPEROT L, RICHARD MJ, MOLENS JP 2005: Mesenchymal stem cells induce apoptosis of activated T cells. Leukemia 19: 1597

QUINTAVALLA J, UZIEL-FUSI S, YIN J, BOEHNLEIN E, PASTOR G, BLANCUZZI SINGH HN, KRAUS KH, O'BYRNE E, PELLAS TC 2002: Fluorescently labeled mesenchymal stem cells (MSCs) maintain multilineage potential and can be detected following implantation into articular cartilage defects. Biomaterials 23: $109-119$

SAITO T, KUANG JQ, BITTIM B, AL-KHALDI A, CHIU RCJ 2002: Xenotransplant cardiac chimera: Immune tolerance of aduIt stem cells. Ann Thorac Surg 74: 19-24

SÝKORA I, DYNTEROVÁ A, HOLDA J, MARHAN O 1983: Chov laboratorních zvířat. Institut výchovy a vzdělávání MZVŽ Praha, vyd. 1, 250 p.

WILLIAMSON RV, STAHELI LT 1990: Partial physeal growth arrest: treatment by bridge resection and fat interposition. J Pediatr Orthop 10: 769-776 
Plate XII

Gál P. et al.: Chondrocytic ... pp. 265-275

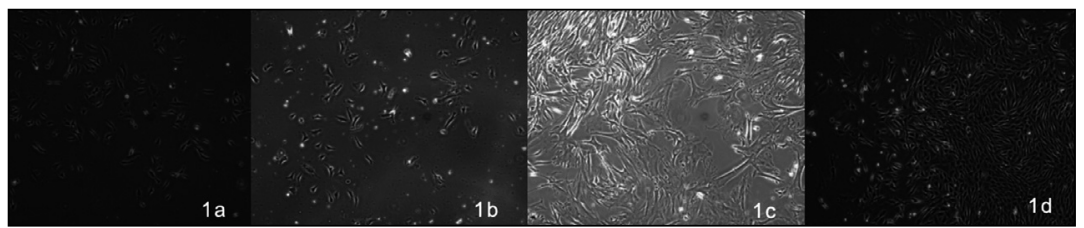

Fig. 1. Expansion of a colony of allogenic MSCs after 5 days (1a), after 10 days (1b), after 15 days (1c) and after 21 days (1d) of cultivation.

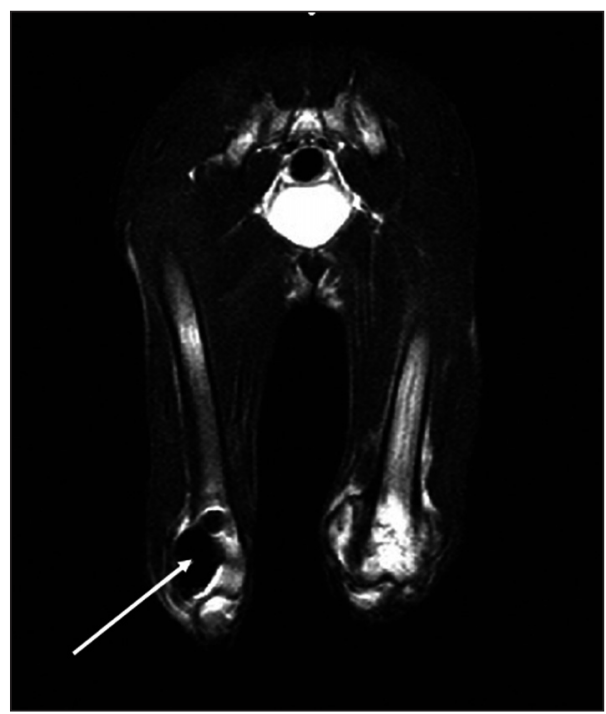

Fig. 2. The arrow shows an artifact created from paramagnetic iron nano-particles with Resovist contrast agent incorporated into transplanted MSCs.

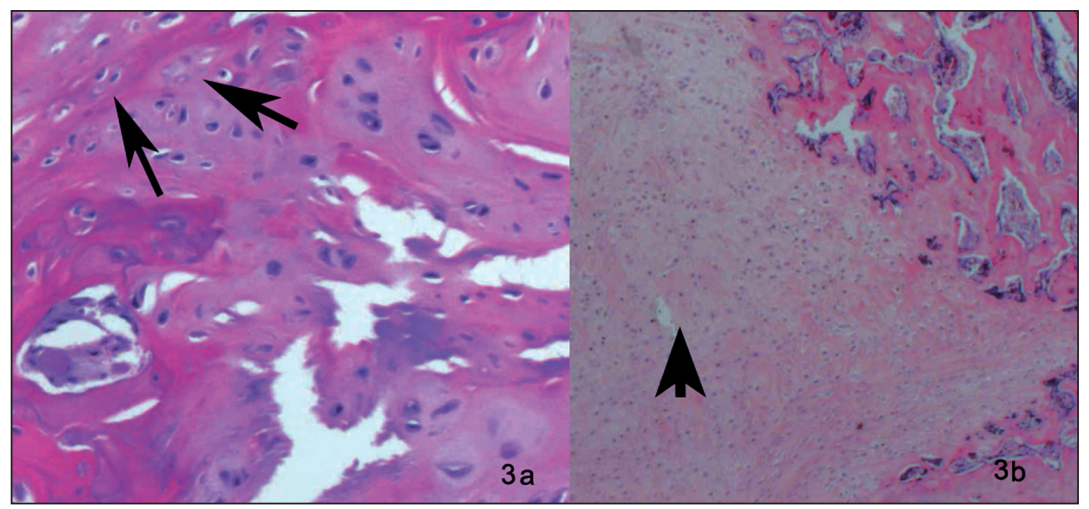

Fig. 3. Histological examination of femoral distal physis of a rabbit after transplantation of allogenic MSCs (H E)

$3 \mathrm{a}$ - cartilage enclaves in the femoral distal physis defect (arrows), magnification $\times 400$

$3 \mathrm{~b}$ - newly created hyaline cartilage in the place of physeal defect (arrow), magnification $\times 20$ 


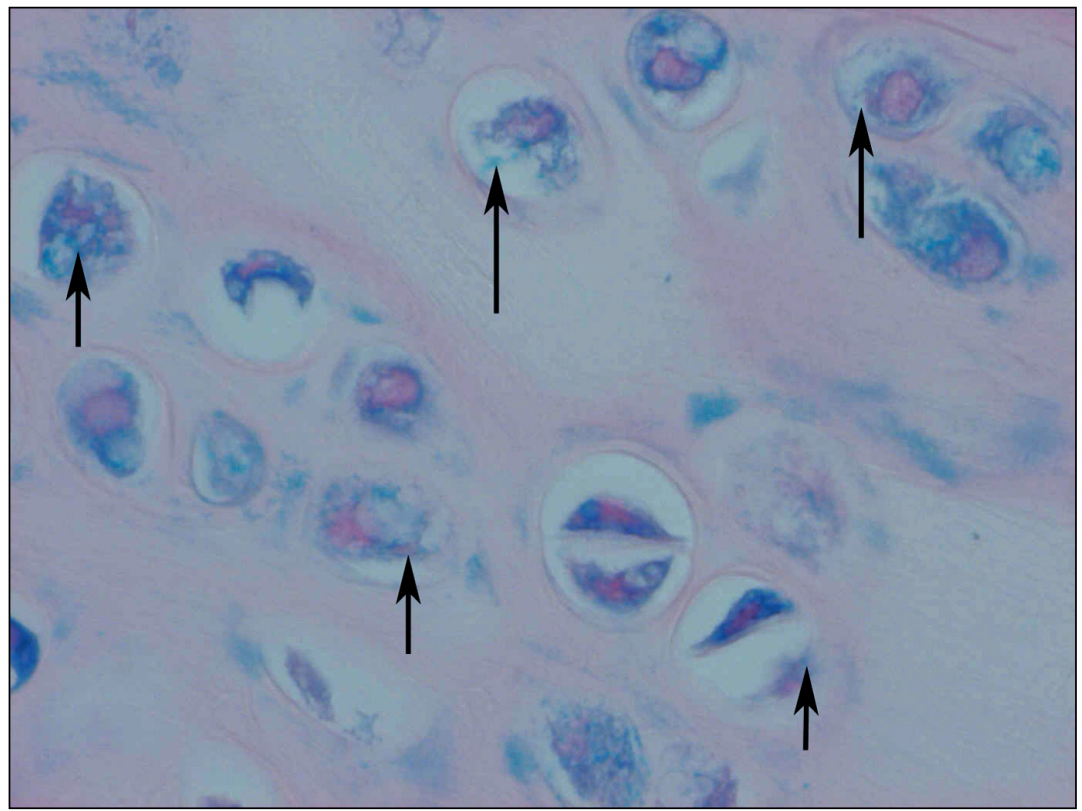

Fig. 4. Resovist granule (arrows) in the chondrocytes cytoplasm (rabbit AL11) differentiated from MSCs - Pearls reaction $(\times 400)$

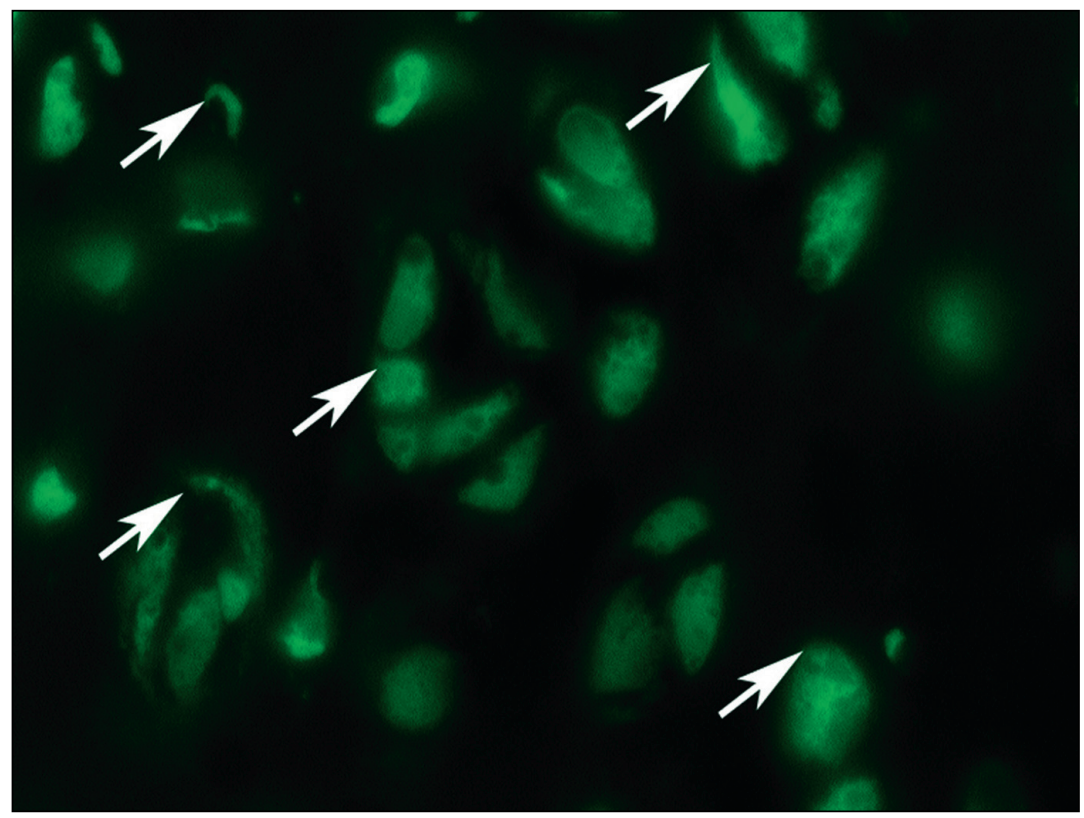

Fig. 5. Immunofluorescence hue DiI on chondrocytes membranes (arrows) differentiated from implanted allogenic MSCs (rabbit AL24) $(\times 400)$ 